\title{
Seizure frequency and bioelectric brain activity in epileptic patients in stable and unstable atmospheric pressure and temperature in different seasons of the year - a preliminary report
}

\section{Częstość napadów i czynność bioelektryczna mózgu u chorych na padaczkę w czasie stabilnego i zmiennego ciśnienia atmosferycznego i temperatury powietrza w różnych porach roku - doniesienie wstępne}

Ewa Motta', Anna Gołba', Anetta Bal'2, Zofia Kazibutowska², Michalina Strzała-Orzeł ${ }^{3}$

IKlinika Neurologii, Śląski Uniwersytet Medyczny w Katowicach

2SPSK Nr 7, Górnośląskie Centrum Medyczne w Katowicach

${ }^{3}$ Oddział Neurologii Szpitala dla Nerwowo i Psychicznie Chorych w Rybniku

Neurologia i Neurochirurgia Polska 2011; 45, 6: 561-566

\begin{abstract}
Background and purpose: An epileptic seizure is a sum of exogenous and endogenous factors affecting an epileptic focus. The aim of the study was to examine the influence of changes in atmospheric pressure and temperature on the increase in the frequency of seizures and changes in EEG in epileptic patients.

Material and methods: The study included 30 epileptic patients (aged 19-54) reporting the influence of changes in weather conditions on the increase in the frequency of seizures for at least 2 years. EEG was performed twice each season at the time of stable and unstable weather conditions.

Results: In stable and unstable weather conditions, epileptic changes in EEG were most often found in winter (in $43.3 \%$ and $63.3 \%$ of patients, respectively). Unstable weather conditions increased the proportion of patients with epileptic changes in EEG also in the other seasons. Unstable weather conditions caused an increase in the frequency of seizures in $40 \%$ of patients in spring, $43.3 \%$ in autumn, $40 \%$ in winter and in approximately $7 \%$ in summer.
\end{abstract}

\section{Streszczenie}

Wstęp i cel pracy: Napad padaczkowy jest sumą wielu różnych czynników zewnątrzpochodnych i wewnątrzpochodnych działających na ognisko padaczkowe. Warunki meteorologiczne mogą być potencjalnym czynnikiem modyfikującym częstość napadów padaczkowych. Celem pracy było zbadanie, czy istotnie zmiany ciśnienia atmosferycznego i temperatury powietrza w różnych porach roku mają wpływ na wzrost częstości napadów u chorych zgłaszających istnienie takiej zależności i czy zwiększenie częstości napadów wiąże się z nasileniem zmian w zapisach EEG.

Materiał i metody: Badaniami objęto 30 chorych na padaczkę (12 kobiet i 18 mężczyzn) w wieku 19-54 lat (średnia wieku 32,6 $\pm 11,3$ roku) zgłaszających od co najmniej 2 lat wpływ zmian warunków atmosferycznych na wzrost częstości napadów. U pacjentów wykonano dwukrotnie badanie EEG w każdej porze roku w czasie stabilnego i zmiennego ciśnienia atmosferycznego i temperatury powietrza. Dane meteorologiczne uzyskano z Instytutu Meteorologii i Gospodarki Wodnej w Katowicach.

Correspondence address: Anetta Bal, Górnoślq̨skie Centrum Medyczne, ul. Ziołowo 45/47, 40-735 Katowice, phone/fax +48 322029592 e-mail:neuropaper@op.pl

Received: 20.09.2010; accepted: 24.05.2011 
Conclusions: In spring, autumn and winter, unstable weather conditions cause an increase in the frequency of seizures in almost half of the epileptic patients but only in $7 \%$ in summer. The increase in frequency of seizures in unstable weather conditions did not correspond in all patients with increase of changes in EEG. The higher proportion of epileptic patients with changes in EEG in unstable weather conditions in all seasons suggests an impact of these conditions on subclinical seizure discharges in this period.

Key words: epilepsy, EEG, seasons, weather conditions.

\section{Introduction}

Diseases with a suggested association between their occurrence or clinical course and specific weather conditions are collectively called meteotropic ones. Biometeorologists think that some components of the weather, although not causative per se, exert some additional burden on the organism and may disturb the homeostasis of the previously affected organs. Those weather-related factors may reveal or exacerbate the disease, and may lead to complications or even death. Meteotropic diseases include musculoskeletal and allergic disorders, ischaemic heart disease, peptic ulcer of the stomach and duodenum, depression, and epilepsy [1].

According to the current views, an epileptic seizure is a sum of multiple distinct endogenous and exogenous factors affecting an epileptic focus. Quite often, epileptic patients attribute the occurrence of the seizure to weather changes, highlighting the impact of atmospheric pressure and different seasons. Studies evaluating the impact of atmospheric pressure and temperature in different seasons on the occurrence of seizures with the assessment of the electroencephalographic recordings are, however, very scarce.

The aims of the present study included: (1) to assess whether alterations in atmospheric pressure and air temperature in different seasons, as confirmed with reliable data from the Institute of Meteorology and Water Management, really cause an increase in frequency of seizures in patients who report such an association, and
Wyniki: W stabilnych i niestabilnych warunkach pogodowych zmiany napadowe w zapisach EEG odnotowano najczęściej w zimie (odpowiednio u 43,3\% i 63,33\% chorych). Zmienne warunki pogodowe zwiększały odsetek chorych ze zmianami napadowymi w zapisach EEG także w pozostałych porach roku (wiosna $26,7 \%$ vs $53,3 \%$, lato $30 \%$ vs $36,7 \%$, jesień $30 \%$ vs 50\%). Zmienne warunki pogodowe powodowały zwiększenie częstości napadów u podobnego odsetka chorych na wiosnę, jesienią i w zimie (odpowiednio 40\%, 43,3\% i 40\%). Wnioski: $\mathrm{W}$ okresie wiosny, jesieni i zimy zmienne warunki atmosferyczne powodują zwiększenie częstości napadów u niecałej połowy chorych zgłaszających taką zależność, a w lecie odsetek takich pacjentów nie przekracza 7\%. Większy odsetek chorych na padaczkę ze zmianami napadowymi w EEG w okresie zmiennych warunków atmosferycznych we wszystkich porach roku mógtby sugerować wpływ tych warunków na subkliniczne wyładowania napadowe w tym czasie.

Słowa kluczowe: padaczka, EEG, pory roku, warunki meteorologiczne.

(2) to determine whether the increased frequency of seizures during unstable atmospheric pressure and air temperature in different seasons is associated with increased abnormalities in EEG performed in that period and compared with EEG during stable atmospheric pressure and air temperature.

\section{Material and methods}

The study comprised 30 patients ( 12 women and 18 men) with epilepsy. Mean age of participants was 32.6 years (standard deviation [SD] 11.3; range 1954 years). All subjects reported the influence of weather changes on increase of seizures for at least two years. None of the participants had a progressive organic brain disorder or any disease other than epilepsy.

Mean age of female subjects was 32.7 years (SD 10.9), and mean age of men was 34.2 years (SD 11.9). Mean duration of epilepsy was 9.9 years (SD 7.8). Complex partial seizures with secondary generalization occurred in $43.3 \%$ of patients; $40 \%$ of patients had complex partial seizures without generalization. Five patients $(16.7 \%)$ had primarily generalized tonic-clonic seizures. In each patient seizures were frequent and occurred with the frequency of several or a dozen or so per month. In almost all patients, seizures occurred at various times of the day. More than a half of patients $(56.7 \%)$ were treated with one antiepileptic drug.

Each patient had an EEG performed twice in each season, once in stable, and once in unstable weather con- 
ditions (i.e. eight recordings per patient). Two hundred and forty EEG recordings were performed.

Data on atmospheric pressure and air temperature were obtained from the Institute of Meteorology and Water Management in Katowice. A significant change of atmospheric pressure was defined as an abrupt decrease of at least $10 \mathrm{hPa}$ within several hours, and a significant change of air temperature was defined as its increase or decrease by at least $5^{\circ} \mathrm{C}$ for two consecutive days.

Each patient kept a diary of seizures and noted dates and hours of seizure occurrence. Treatment was not modified during the study period.

Data were collected and managed with Excel 2000 (Microsoft), and statistical calculations were performed with a licensed statistical package, Statistica v.6.0 PL (StatSoft). A $p$-value $\leq 0.05$ was considered significant.

Student's $t$-test or Wilcoxon test was used to assessed the associations of EEG in stable and unstable weather conditions. Chi-square test or Fisher exact test was used to assess qualitative data.

The study protocol was approved by the Bioethical Committee.

\section{Results}

Epileptiform discharges (generalized and focal discharges of sharp waves, spikes, sharp-and-slow-wave complexes, spike-and-wave complexes, or polyspikeand-wave complexes) in EEG during stable weather conditions were noted in the highest proportion of patients

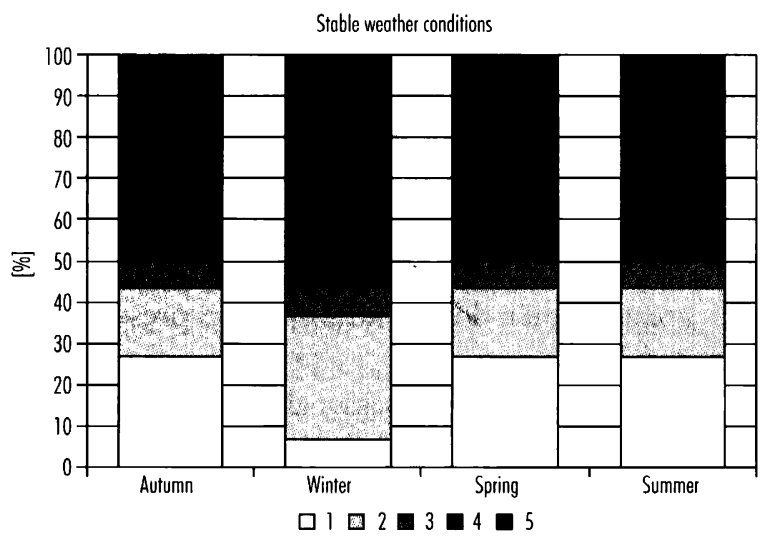

$$
\begin{aligned}
& \text { 1. Normal EEG } \\
& \text { 2. Focol non-epileptic obnormalities } \\
& \text { 3. Focol epileptiform obnormalities } \\
& \text { 4. Generolized non-epileptic abnormalities } \\
& \text { 5. Generalized epileptiform abnormalities }
\end{aligned}
$$

Fig. 1. EEG findings recorded in all seasons in stable weather conditions among epileptic patients
$(43.3 \%)$ in winter. The smallest proportion of normal EEG results was found also in winter (Fig. 1). During unstable weather conditions, the highest percentage of patients with epileptiform discharges $(63.3 \%)$ was also noted in winter. Unstable weather conditions increased the proportion of patients with epileptiform discharges in EEG (spring, $26.7 \%$ vs. $53.3 \%$; summer, $30 \%$ vs. $36.7 \%$, autumn, $30 \%$ vs. $50 \%$ ) (Fig. 2).

When all types of EEG abnormalities were considered (both epileptiform and non-epileptiform, such as generalized or focal theta activity), it was noted that unstable weather conditions increased those abnormalities most commonly in spring ( $56.7 \%$ of patients) and in winter ( $50 \%$ of patients) (Fig. 3).

Unstable weather conditions increased the frequency of seizures in similar proportions of patients in spring, autumn, and winter $(40 \%, 43.3 \%, 40 \%$, respectively) (Fig. 4).

Among patients who experienced an increase in seizure frequency in spring in unstable weather conditions, $75 \%$ also had an increase of EEG abnormalities (both epileptiform and non-epileptiform ones).

Neither of the two patients who experienced an increase in seizure frequency in summer in unstable weather conditions exhibited changes in EEG. An increase in seizure frequency during autumn and spring in unstable weather conditions corresponded with the increase of EEG abnormalities (both epileptiform and nonepileptiform ones) in $61.5 \%$ and $41.7 \%$ of patients, respectively.

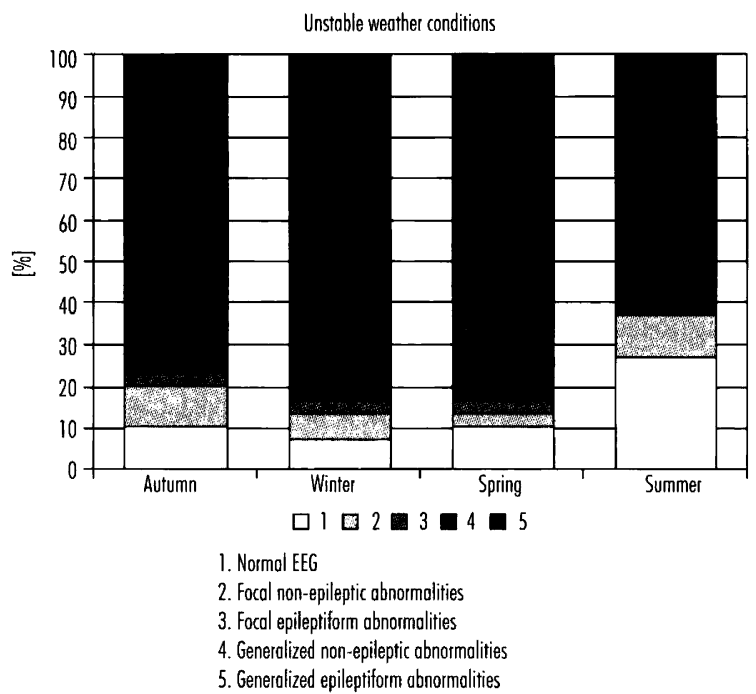

Fig. 2. EEG findings recorded in all seasons in unstable weather conditions among epileptic patients 


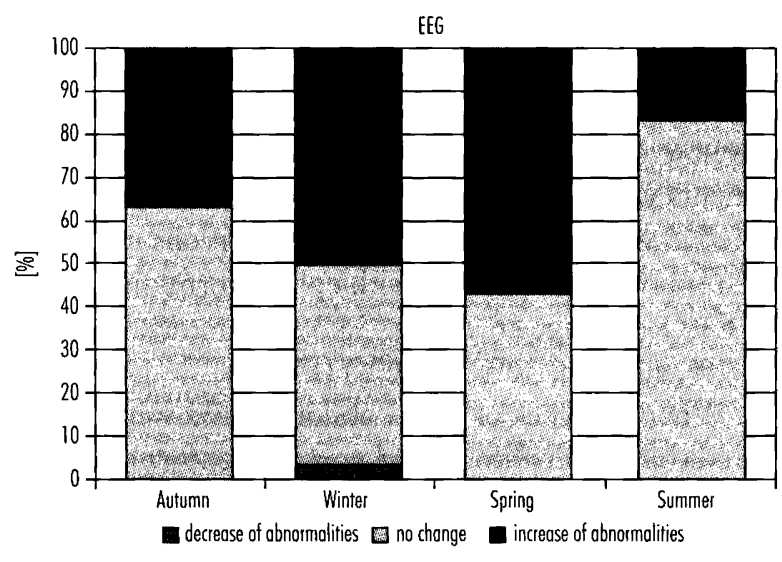

Fig. 3. Comparison of EEG findings in all seasons between stable and unstable weather conditions

\section{Discussion}

The occurrence of seizures was already attributed to weather changes in Hammurabi's Code. Daily clinical practice abounds in epileptic patients who report an increase in the frequency of seizures 'as the weather is about to change'. Those reports cannot be confirmed with reliable meteorological data that might reveal the unstable weather conditions at the time of increased seizure frequency. The present paper attempts to verify the hypothesis that unstable weather conditions cause an increased seizure frequency in patients with epilepsy.

It was noted recently that weather changes might affect both acute and chronic disorders. Such an influence was revealed in relation to rheumatoid arthritis, cerebrovascular disorders and myocardial infarction [2-5].

The season-related prevalence of peptic ulcer of the stomach and duodenum is well known, while it is rather rarely noted also that meteorological factors may contribute to the occurrence of complications of peptic ulcers, i.e. gastrointestinal bleeding and ulcer perforation.

Between April 2005 and April 2006, Swedish authors performed a telemetric video-EEG recording in $196 \mathrm{pa}-$ tients with various types of attacks, including 96 patients diagnosed with epilepsy, in order to establish the link between frequency and type of the seizures, and daily changes in atmospheric pressure. There were 159 seizures recorded, along with 59 pseudoepileptic seizures and 40 attacks of unclear aetiology. Among patients with proven epilep$\mathrm{sy}$, an increase of seizure frequency was recorded during changes of atmospheric pressure, particularly if the change was greater than $5.5 \mathrm{mBar}$ per day [6].

Rüegg $e t$ al. made an attempt to assess the factors affecting the admission of patients with status epilepticus to the intensive care unit. An analysis of 184 cases showed

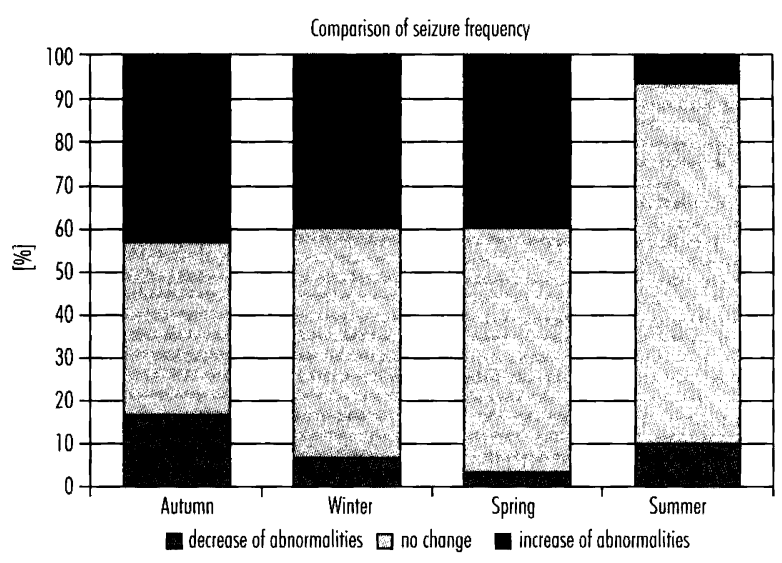

Fig. 4. Comparison of seizure frequency in all seasons between stable and unstable weather conditions

the significant circadian rhythm of such admissions, with the maximum between 5 and 6 p.m. and with the minimum in the early morning. No significant rhythmic changes were noted in longer periods, i.e. weekly, monthly or regarding the seasons. The frequency of status epilepticus increased in sunny days and with longer insolation. Higher air humidity, high temperature and cloudy days were protective factors. The authors also noted that the risk of non-convulsive status epilepticus was higher in summer [7].

Horwat-Kaczmarek and Rościszewska in their retrospective and prospective analysis of 1217 seizures in 55 epileptic patients in different months showed that tonic-clonic and partial seizures occurred significantly more frequently in summer months (July and August) when compared with the spring months (March and April). This association was noted in all years except for 1983, when the smallest daily changes in weather conditions were noted in particular months. The authors noted that the number of seizures was greater with greater daily temperature fluctuations. The correlation with daily fluctuations of atmospheric pressure was not so evident, but it could be noted that the number of seizures was greater when lower atmospheric pressure was recorded [8].

Sobaniec $e t$ al. analysed seasonal frequency of seizures in children with epilepsy and obtained different findings: epileptic seizures were significantly more frequent in spring and autumn [9].

Seasonal rhythm of seizure activity may be associated with the seasonal rhythm of melatonin excretion (in addition to the diurnal rhythm) which is associated with changes of the insolation in different seasons $[10,11]$. Reports on that topic are equivocal, however. Arendt 
et al. suggest that the melatonin concentrations are the highest in summer and winter, and the lowest in spring and autumn [12]. Martikainen et al. noted two peaks of melatonin excretion, in December and May, and the lowest melatonin concentrations in August [13]. BeckFriis $e t$ al., on the other hand, did not find differences in melatonin excretion in various seasons but noted the shortening of the night increase of melatonin concentration in winter when compared with data from summer [14].

The frequency of seizures in epileptic patients in stable and unstable weather conditions in various seasons was not compared before.

Participants of our study who reported an increase of seizure frequency during unstable weather conditions did not claim precisely whether it was related to the changing air temperature or to the changing atmospheric pressure, but declared that both those factors contributed simultaneously. Therefore, a combined analysis of unstable weather conditions, including both those factors, was performed.

An analysis of EEG recordings in different seasons showed that the smallest proportion of normal EEG recordings was noted in winter, during both stable and unstable weather conditions. Epileptiform discharges in EEG were noted more frequently in winter, and they became more severe in unstable weather conditions. Those findings are in line with the report of Danesi [15], who recorded EEG in various seasons among patients susceptible to photic stimulation and found that epileptiform discharges were most prevalent in winter. The author claims that this finding proves greater neuronal excitability and believes that this unclear pathomechanism might be associated with the lower air temperature and insolation in winter [15]. The same author compared interictal EEG recordings between British and Nigerian epileptic patients. It was found that interictal abnormalities, such as spike-and-wave complexes, photoparoxysmal reaction, and unspecific changes, were significantly less common in Nigerian (15.7\%) than British (52.9\%) patients, regardless of sex or age. This finding was explained not only by ethnical factors, but mainly by the greater insolation in the tropics [16].

Sobaniec et al. assessed interictal EEG recordings in children with epilepsy and found a marked increase of EEG abnormalities (increased amount of theta and delta waves) in spring and autumn [9].

It was noted in the preset study that unstable weather conditions increased the proportion of patients with epileptiform discharges in EEG in all seasons, but the difference between stable and unstable weather conditions was smallest in summer.

Increase of seizure frequency during unstable weather conditions corresponded with increased amount of EEG abnormalities but not in all patients; no EEG abnormalities were recorded in the EEG of either patient with increased seizure frequency in summer. It is possible that plausible EEG abnormalities were not recorded only during the 30 -minute recording in those patients, but the smallest proportion of patients with increased seizure frequency during unstable weather conditions in summer, and the greatest proportion of patients with stable seizure frequency during that period, might suggest the smallest neuronal seizure excitability in summer. The results obtained in this study should be replicated in a larger study.

\section{Conclusions}

1. Unstable weather conditions cause an increase in the frequency of seizures in almost half of the epileptic patients in spring, autumn and winter but only in $7 \%$ in summer.

2. The increase in frequency of seizures in unstable weather conditions did not correspond in all patients with increase of changes in EEG. The higher proportion of epileptic patients with changes in EEG in unstable weather conditions in all seasons suggests an impact of those conditions on subclinical seizure discharges in this period.

\section{Disclosure}

Authors report no conflict of interest.

\section{References}

1. Kozłowska-Szczęsna T., Błażejczak K., Krawczyk B. Bioklimatologia. IGiPZ PAN, Warszawa 2002.

2. Janus D. Wpływ pogody na zdrowie człowieka. Lek Wojsk 2005; 81: 46-49.

3. Jamison R.M., Anderson K.O., Slater M.A. Weather changes and pain: perceived influence of local climate on pain complaint in chronic pain patients. Pain 1995; 61: 309-315.

4. Berginer V.M., Goldsmith J., Batz U., et al. Clustering of strokes in association with meteorologic factors in the Negev Desert of Israel: 1981-1983. Stroke 1989; 20: 65-69.

5. Rogot E., Padgett S.J. Association of coronary and stroke mortality with temperature and snowfall in selected areas of the United States. Am J Epidemiol 1976; 103: 565-575. 
6. Doherty M.J., Youn C., Gwinn R.P., et al. Atmospheric pressure and seizure frequency in the epilepsy unit: preliminary observations. Epilepsia 2007; 48: 1764-1767.

7. Rüegg S., Hunziker P., Marsch S., et al. Association of environmental factors with the onset of status epilepticus. Epilepsy Behav 2008; 12: 66-73.

8. Horwat-Kaczmarek M., Rościszewska D. Analysis of correlation between seizure incidence and atmospheric pressure and temperature in particular months during years 1982-1987. Abstracts 13 ${ }^{\text {th }}$ Congress of Neurology, Gdańsk 1987.

9. Sobaniec W., Kutak W., Bielewicz B. Analiza ilościowa EEG w aspekcie zmienności sezonowej u pacjentów z przewlekłą padaczką. Epileptologia 2005; 13 (Suppl 1): 64.

10. Słowińska-Klencka D., Lewiński A. Rola melatoniny w fizjologii i patologii człowieka. Dobowy rytm wydzielania melatoniny. Znaczenie melatoniny $w$ fizjologii rozrodu. Melatonina a oś podwzgórze-przysadka-kora nadnerczy. Post Hig Med Dośw 1993; 47: 209-220.

11. Sewerynek E., Lewiński A. Znaczenie melatoniny dia zachowania zdrowia - ryzyko związane $\mathrm{z}$ występowaniem jej niedoboru. Żywność, Żywienie, Prawo a Zdrowie 2000; 4: 396-407.

12. Arendt J., Wirz-Justice A., Bradtke J. Annual rhythm of serum melatonin in man. Neurosci Lett 1977; 7: 327-330.

13. Martikainen H., Tapanainen J., Vakkuri O., et al. Circannual concentrations of melatonin, gonadotrophins, prolactin and gonadal steroids in males in a geographical area with a large annual variation in daylight. Acta Endocrinol 1985; 109: 446-450.

14. Beck-Friis J., Von Rosen D., Kjellman B.F., et al. Melatonin in relation to body measures, sex, age, season and the use of drugs in patients with major affective disorders and healthy subjects. Psychoneuroendocrinology 1984; 9: 261-277.

15. Danesi M.A. Seasonal variations in the incidence of photoparoxysmal response to stimulation among photosensitive epileptic patients: evidence from repeated EEG recordings. J Neurol Neurosurg Psychiatry 1988; 51: 875-877.

16. Danesi M.A. Electroencephalographic manifestations of grand mal epilepsy in Africans: observation of relative rarity of interictal abnormalities. Epilepsia 1988; 29: 446-450. 